\title{
Defensive manor complex in Rzemień as one of the unique objects of cultural landscape of the Podkarpacie region
}

\author{
Paulina Raś ${ }^{1}$, Krystyna Pudelska, ${ }^{1, *}$, and Kamila Rojek $^{1}$ \\ ${ }^{1}$ University of Life Scences in Lublin, Department of Ornamenatal Plants, Dendrology and \\ Ladscape Architecture, 20612 Lublin, Głęboka Str. 28, Poland
}

\begin{abstract}
Cultural landscape is ,the space historically shaped as a result of human activity, including products of human civilization and elements of nature" [1]. The valuable areas of particular historical, artistic and scientific values, which are a sign of the previous epochs, can be found in the present Podkarpacie region, which is the ethnic, political and religious border region. One of the objects of defensive landscape of the Podkarpackie voivodeship is a manor complex in Rzemień. This 15th century knight-fortified tower built among the marshes and wetlands of the Wisłoka River represents a bastion system of the so called Dutch school and it is the oldest preserved part in this historical building. Next to it there is the 19th century manor and park complex of the Szaszkiewicz family. Over the centuries the area and the layout of the whole historical complex has undergone many changes. Currently, it covers the area of 16 ha and since 1971 it has been inscribed in the list of historical monuments of the Podkarpackie voivodeship. Both in the closest surrounding of the oldest castle as well as in the park one can find a valuable tree stand and the remains of historical plants. These are monument trees of over 400 years old (eg. Quercus robur L.). Nowadays, the area of the defensive manor together with soil fortifications is private property. It serves as an example of good protection activities of defensive landscape. This has been confirmed by a distinction which residential-fortified tower with bastion fortifications received in 2014 in „Zabytek Zadbany” competition. The rest of the complex is a garden, which plays an educational role and it belongs to Agriculture School. The aim of the study is to present the preserved cultural and natural values of a defensive manor complex in Rzemień.
\end{abstract}

\section{Introduction}

The Podkarpacie region has always been of a great startegic importance. Preserved up to our times, defensive heritage objects are an important element of a cultural landscape of the region with trade routes leading from the west to the east, in the direction of Ruthenia through Przesmycka gate and from the west to the south through the Carpathian mountains. To defend these trades as well as to protect against the invasion of the Tatars, Cossacks, Russians or Swedish army, a lot of fortifications were built around the human settlements

*Corresponding author: kpudelsk@autograf.pl 
and castles. The defence manor complex in Rzemien is an example of a fortified building in a good technical condition, which is well maintained and serves as a residential place.

\section{Object localisation}

Rzemien is in Przecław commune, in Mielec district. As a result of many cultural layers in the mentioned area, one can find objects from different historical periods: a castle (i.e. residential-fortified tower) from the first half of the 15 th century, bastion ground fortifications from the first half of the 17th century and the Szaszkiewicz family palace with a landscape park from the turn of the 19th and 20th centuries. The whole area covering about 15.40 ha (including 6.10 ha of surface water) was entered on the list of historic monuments under the number 272 from 29th of July 1971. Nowadays, the area under protection is divided into the ,old" and the „new” park (Fig. 1.). On the discussed area there are also school buildings and a cloakroom next to a sports field built in the 60s of the 20th century.

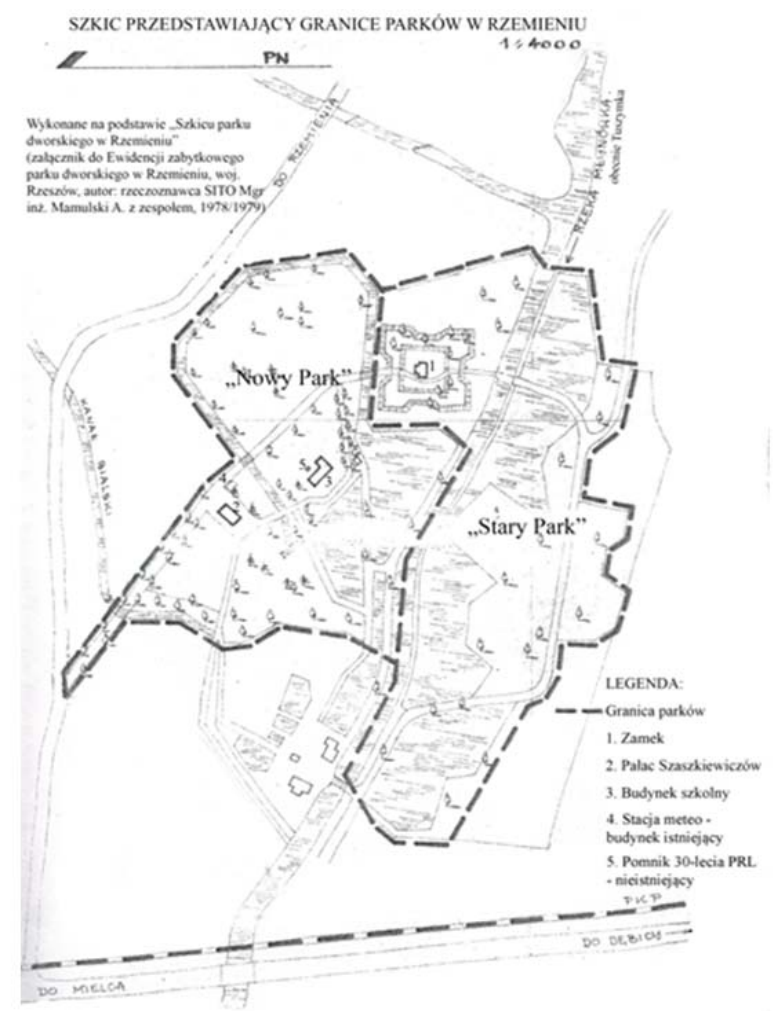

Fig. 1. Draft of the park in Rzemień at the turn of 1978/1979 [12].

\section{Legal condition of the building}

According to the decision about entering the list of immovable historical monuments of the Podkarpackie voivodeship under number 272 from the 29th of July 1971, the monument including a defensive manor, ground fortifications of a manor, bastion fortifications of precastle area, moat, park with trees and bushes covering dikes and a pre-castle area, a pond system and the Szaszkiewicz family castle are under legal protection. The decision is justified by the fact that: „A defensive manor in Rzemien belongs to medieval residential- 
fortified towers in which residential, farm and defensive functions were concentrated in one building. The manor, with a bastion system elevated in the 17th century and a pre-castle area, was a defensive residence of the Lubomirski, Sanguszko, Stadnicki, Rey, Bogusz, Szaszkiewicz families...." and "Park in Rzemien is an example of the 19th century landscape park where many historical monuments blend in perfectly with a pre-castle area and its suburbs. '"[2].

On the basis of the study of conditions and directions for land planning of Przecław commune, Mielec district, some decisions, spatial policy planning of a commune and the directions of spatial planning from the 29th of September 2000 it can be stated that the area under discussion i.e. the 19th century manor landscape park in Rzemien belongs to an ecological corridor and is under conservational protection [3]. The whole area of Rzemień requires revalorisation, some changes and also new local spatial plans. "Rzemień a landscape complex, highlighting its cultural and tourist values also including natural ones by forestation planning to get nature continuation with the Wistoka River"'[3].

\section{History and changes in the surroundings of a defensive manor}

At the turn of the 14th and 15th centuries in the areas of the present south-east Poland there was a trade artery connecting Sandomierz with Bardiów and Koszyce in Hungary along the valley of the Wisłoka River going through Dębica, Pilzno and Dukla. In Mielec and Przecław defensive castles were built to protect this trade route. The tower in Rzemien on the intersection of Sandomierz and Lviv routes played such a role [4]. The location of the tower was not coincidental as it was situated on a difficult to reach, wet and low area surrounded with ponds from all sides.

The note from 1508 in which Rzemień was defined as a castrum (,Stanisllaus senior accepit castrum Rzemyen et oppidum Zuchovo") [5] indicates the creation of a tower in the 15 th century. In the 16th century Rzemien passed into the hands of the Tarnowski family originating from Jan Feliks called Szram. In Matricularum Regni Poloniae Summaria IV, part I-III Warsaw 1910 there is a note from 1522 describing Stanisław Tarnowski as ,lord of Rzemień" - ,arx Rzemyen” [6]. From the 16th century also comes a document describing in details the state of the Rzemien estate - it is the last will of Stanisław Tarnowski from 1546 dividing the estate between his wife Katarzyna from Dąbrowica and his sons Wojciech and Jan. On the basis of this document it can be stated that the castle in Rzemien in that time, apart from being a fortification, also played a residential role ,Domus seu Turris" [7]. In another document there is also mentioned a garden next to the castle for the first time. Probably it had a utility function and it was set up for the needs of the inhabitants of the castle [8]. There is also an orchard and a vegetable garden "Pomarium et hortum” and the castle grounds buildings , antecastro alias Przegrothek” [8]. One can find some information about the ponds surrounding the castle described as Białe, Okolin, Mały Staw (Sadzawka) and Wadowski Staw „piscinula alias Sadzawka sub castro Rzemień (...) Piscina dicta Wadowski Staw cum piscibus et dimessionibus alias spusty (...) Piscina Okolin dicta et alia piscina Biate dicta". The last will of Stanisław Tarnowski from 1546 describes the tower as a main brick building of a manor complex surrounded by a soil dike of a courtyard „(...) Muratam Turris in medio Castri sitam (...)”. Two wooden platforms mentioned in the document led from the dike to the tower and then from a wooden outhouse to a chamber ,(...) ad domum seu turrim de vallo transitum ducentes (...) alterum de praefata caminata eiusdem Turris ad alterem partem valli ad stubellam i ligneam ducentem (...)". On the courtyard there were servants' quarters and farm buildings, a big wooden house, ancient house and a pantry ,cameras propter servitores a coquina (...) Domo magna lignea (...) domuncula antiqua (...) promptua” [9].

After the death of Stanisław Tarnowski (a son of Wojciech Tarnowski) in 1586, Rzemień passed into the hands of his wife Zofia nee Mielecka and then to her cousin Anna 
Ocieska nee Mielecka 2-o voto Rotowska, who in 1616 sold Kolbuszowki and Rzemieński estates to Stanisław Lubomirski. On the basis of the last will of Stanisław Lubomirski from 1640 it can be stated that Rzemień was fortified. ,, Cannons however iron which there are in Rzemień, Połonne and Lańcut should stay there" However, the 1620s was the time when a round corner tower was built, dikes were rebuilt and a cannon was placed by Stanisław. It is proved by the date ' 1625 ' in the fronton portal in the supraporta' of the tower and the fact that the area of Rzeszów was being fortified as a result of an unstable situation in the east [7]. A note in I edition of 'Polonia' by Szymon Starowolski from 1632 mentions the fortifications in Rzemien before 1632: „There are numerous castles of the lords, three of which are of special importance: Rzemien as the most fortified, Wiewiorka as the best located and Baranów - the most exclusive one" [6].

Over the years, since 1710 to about 1830 , the Rzemien estate changed its owners. These were the Lubomirski and Sanguszko families and again the Lubomirski, Lasocki, Stadnicki and Rey families. At this time, according to the note from the work of TeodorowiczCzeplińska from 1959, the castle did not change [7].

However, the information in "Inwentarz klucza rzemieńskiego" originating from the 19th October 1719 [11] as well as a cadastral map from 1850 show some changes around the castle. These changes are connected with the area closest to the castle, eg. castle grounds where three wooden buildings appear and Italian garden (Fig. 2.) Decorative-utility garden in Italian style located in the castle grounds consists of six sections divided by perpendicularly crossing paths. The second, smaller one, consists of four sections located in the west side of a castle grounds moat. Both gardens divided into sections are surrounded by a line of hornbeams, the remains of which one can find nowadays as relicts of the south line [12]. On a cadastral map from 1850 the castle is surrounded by walls and ponds and on dikes and along driveway to the castle there grow trees.

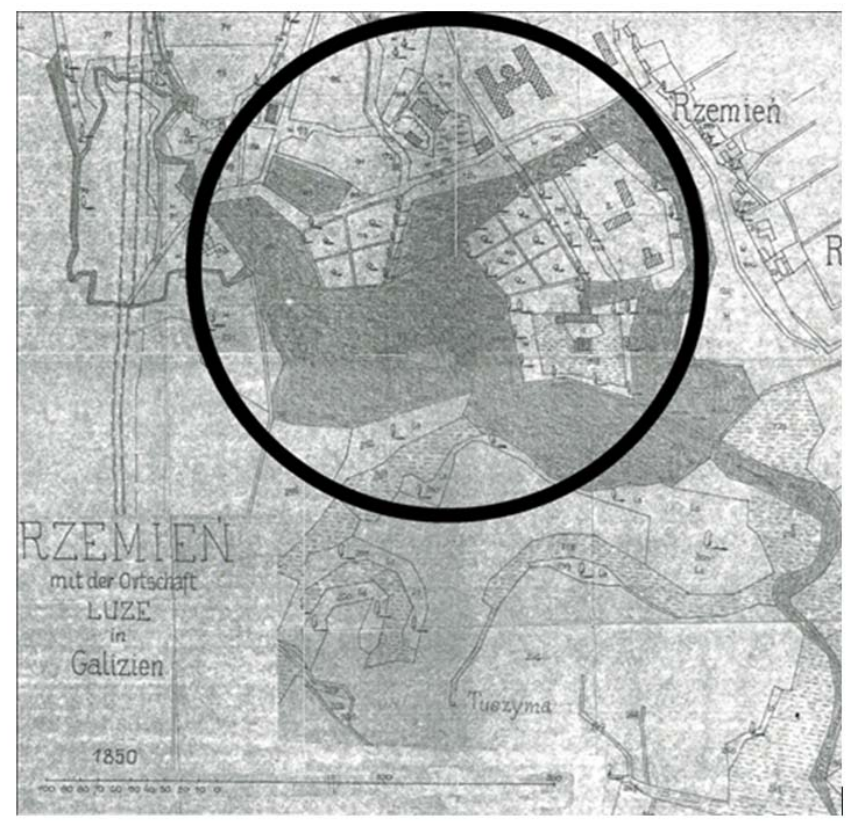

Fig. 2. A copy of a cadastral map from 1850 [12].

\footnotetext{
${ }^{\dagger}$ Supraporta (lac. supra portam -over the door) decorative surface or decorated surface of a rectangular shape as a result of the wall division, placed over the door, in a wooden frame or a stucco. Decorated with fresco, a bas-relief or stuccowork [10].
} 
The 19th century brought changes. In 1832 a daughter of Kajetan Aleksander Rey got married to Feliks Bogusz who according to a note on the inscription plate in 1857 finished the pseudo-gothic reconstruction of the tower. The next evidence of the castle existence together with its surrounding garden in Italian style is a description in 'Geographical dictionary of The Polish Kingdom and other Slavic countries' published in 1889: ,Rzemien (...) The castle is almost four-storey and four-sided tower. It was protected by the marshes with a long bridge over them, and in later times-ditches and dikes with the sign left after them. There was also a garden with cut grass" [13].

In the second half of the 19th century in the area bordering the castle from its north side, a landscape park was created, composed of one species' groups of trees. It presented the species similar to romantic. In 1907 the Earl Gustaw Szaszkiewicz lets Zygmunt Hendl, a Cracow architect, who was a conservator of the Tarnów and Rzeszów regions, reconstruction of the palace from 1869, located near the tower (Fig. 3.). A one - storey palace was rebuilt into a more monumental eclectic building $[15,16]$. Zygmunt Hendel in the place of the previous outbuilding of the palace suggested building a wing and a new, two-storey part. The „old" palace after reconstruction constituted a middle part of a new building, highlighted by a risalit in a form of a tower crowned with an angular roof with a spire. In this part there is a viewing terrace on the first storey supported with four pillars [16]. On the map from 1898 there is also a driveway with a round flower bed at the front south elevation (Fig. 3.).

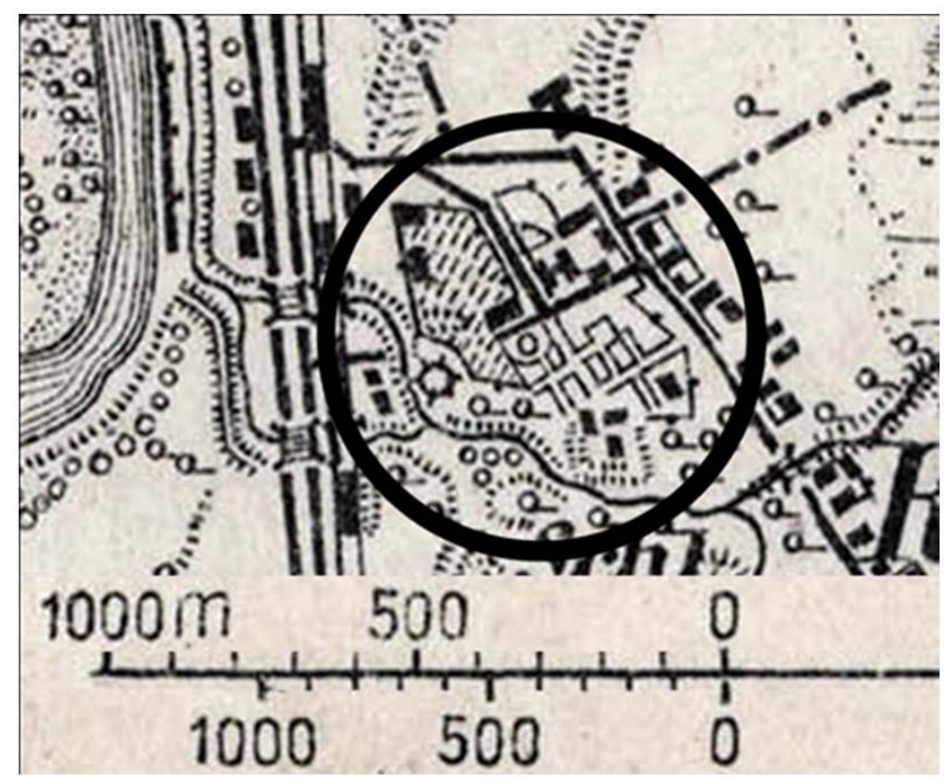

Fig. 3. A copy of Galicia map from 1898 zone 5.col XXV. Ropczyce and Dębica [14] with a region under discussion marked on it by Paulina Raś.

Jaderny's photography from the beginning of the 20th century shows this characteristic for the landscape parks element - a driveway (Fig. 4.) One can also see a stone fountain on the axis of the main entrance situated in a garden depression. 


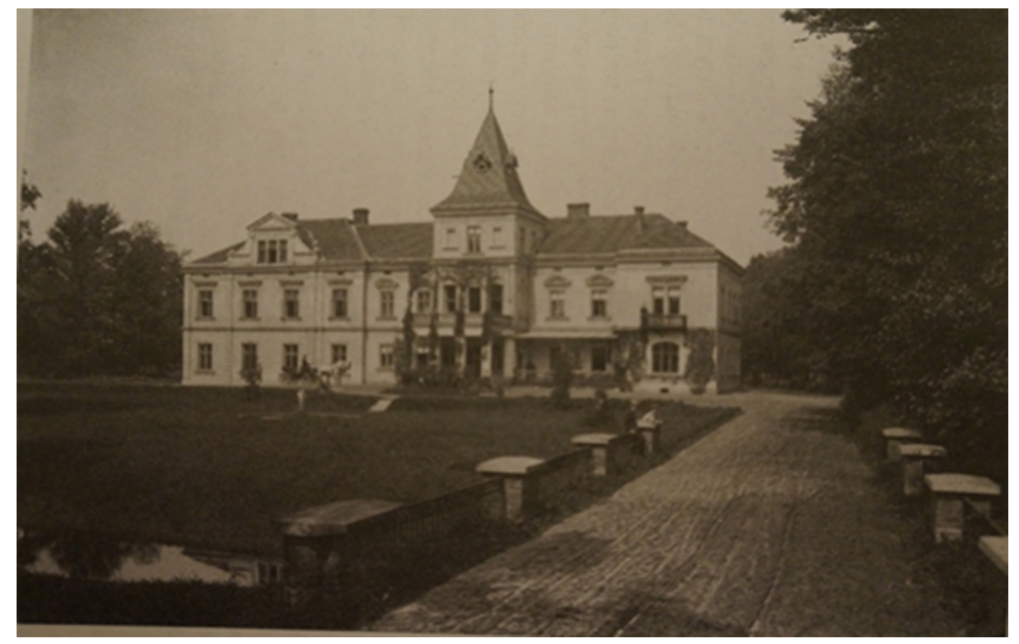

Fig. 4. A. Jaderny's photography from the 20th century showing the front south elevation of the palace [17].

From 1896 to 1945 the owner of the Rzemien estate was the Szaszkiewicz family. On the basis of a decree from 26th November 1944, the Rzemien estate became nationalized and then divided up. After 1945 the area of the castle, the palace and the whole garden complex - the 'new' and the 'old' park as well as a part of the agricultural area was delegated to National Agricultural Vocational School, which in 1979 was changed into the Professor Władysław Szafer Agricultural Schools Complex [18].

The south-east area of the 'old' park with a lot of ancient tees influencing the park layout, became the property of farmers. In 1963 a castle and its fortifications were excluded from use. Since the 1990s a castle, a significant part of the 'old' park and six out of the eight ponds have had private owners. In 2008 the owners of the castle changed. In the 60 s and until the end of the 1990s the Szaszkiewicz family palace served as a boarding school. Currently, the building is not used, it is suffering damage and it requires a full reconstruction.

\section{A castle and soil-bastion fortifications}

A castle in Rzemień is built from full brick on calcareous mortar in a Polish layout, on a square $(14 \times 14 \mathrm{~m})$. To the four-storey tower a rectangular vestibule (a double-shingled roof) and a cylindric corner tower (four-storey conic-shaped roof) and from the south a rectangular outhouse were added. Foundations were made from hewn stone and in the upper part from brick. Under the foundations there is an oak grating put on a compacted ground with oak logs.

Fortifications in Rzemien can be included in bastion fortifications of the Dutch school [20]. The first mention of fortifications around the tower appear in 1546 in the last will of Stanisław Tarnowski. This description shows that there was then an entrance gate and a drawbridge. Present ones were probably built in 1620 by Stanisław Lubomirski. In 1784 a corner tower with a loggia next to north-west dike connected with a gate and a big rectangular building next to south-east dike were mentioned. A corner tower with a loggia were stone, two-storey, crowned with an attic. In a ground storey there was one vaulted

Gothic brickwork, also called Polish, based on bricklaying of column heads and each head is moved half the length in comparison to a row of bricks over and under it. The advantage of it is esthetic drawing of concrete surface [5]. 
room. The second storey was octagonal in shape and that was a viewing loggia. The loggia in Rzemien had an original form, probably it was built by adding the previous corner tower at the beginning of the 17th century [15]. Around 1852, thanks to Gustaw and Antoni Szaszkiewicz, gate buildings on the north-south axis were created [20]. The north gate is a two-storey building situated on a dike and the south gate is one-storey building embedded in dikes [7]. Dikes of castle grounds were established on a plan of an irregular pentagon. They were based on a river, moat and ponds. Presently preserved dike parts are narrow, short and have a maximum height of $2 \mathrm{~m}$. At the turn of the 19th and 20th centuries the north dike curtain was partly dismantled at the level of the Szaszkiewicz family palace. Out of five bastions, the most recognizable is the north-west bastion [7].

In the late 1990s, a private owner made an injection of ground under the building, fastened the walls of the building with anchors and supported it with special glues to make the castle regain stability. The roof truss is wooden, covered with conventual tiles with ridges in the corners. At the ground level there are vaults ceilings and on the storey it is cross vaulted [19].

\section{Historical plant forms}

The most valuable plant forms on the area of a defensive manor complex in Rzemien are a single species of pedunculate oak, which are estimated to be 400 years old. These trees grow on the soil dikes near the south-west bastion and in the place of a bed garden divided into sections marked on a cadastral map from 1850 (Fig. 5.). A very important element of the park in Rzemień, taking into account its historical origin, is a hornbeam row which marks the south border of a central clearing (currently, along the road leading to the school facilities in the south part of the 'new' park). Comparing a cadastral map from 1850 and the modern base map, it can be concluded that the row can be the result of the former sixsection decorative-utility garden of an Italian style.

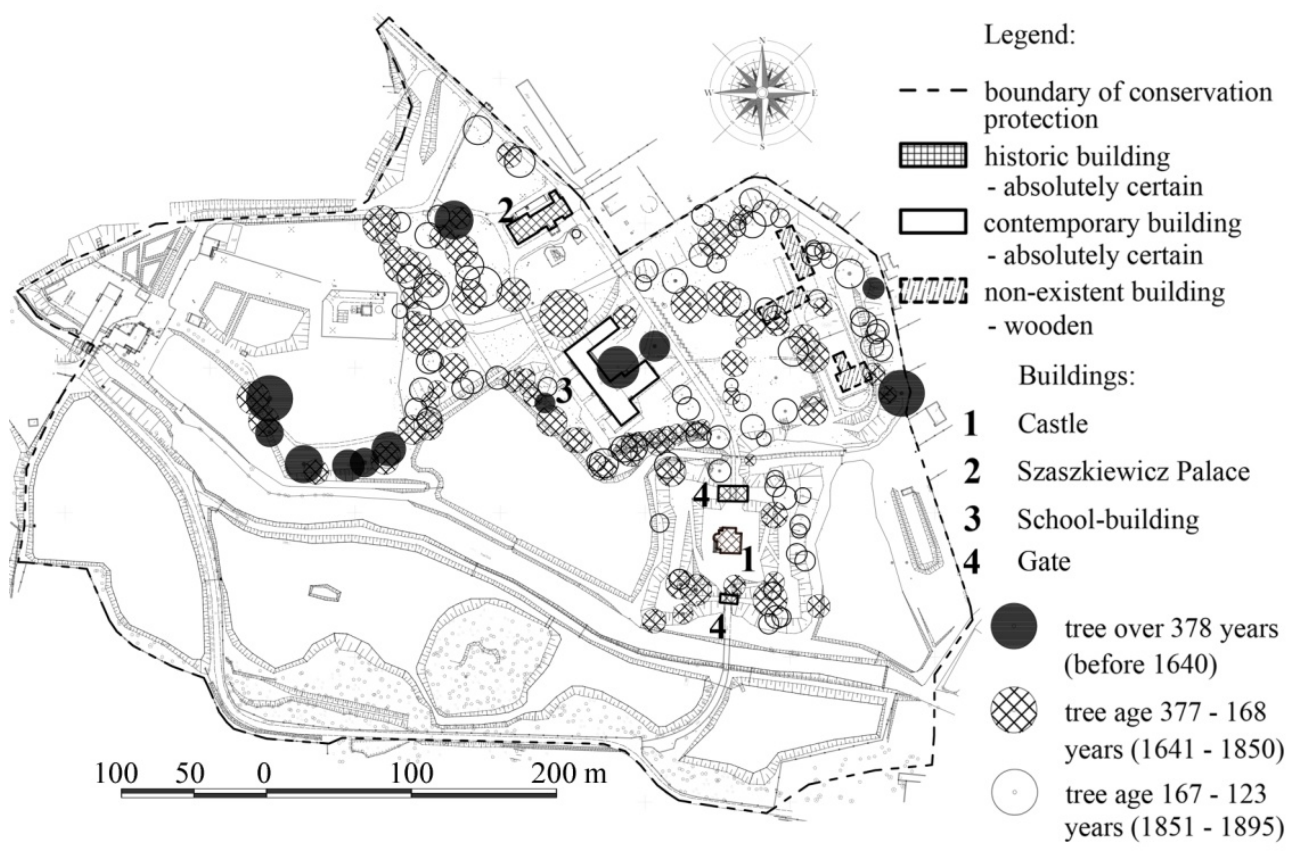

Fig. 5. A map of the oldest trees in the surrounding of a defensive manor and a palace in Rzemien state from 2013 [Prepared by P. Raś]. 
In the second half of the 19th century in the place of the garden divided into sections up to the borders of the ramparts a landscape park was built in a romantic style, changed in the 20th century into a landscape park. It was going to compose ideologically with the Szaszkiewicz family palace. An important element of a new garden composition there were huge interiors with an open view leading in the direction of a castle and ponds (currently, a school building and trees cover them). There are single trees on these clearings (so called lone trees) and one or two species' groups. Currently one can find there such species as oaks, ashes and limes at the age of 360 or trees from the age of 160-359.

A landscape park in Rzemien is based on the main axis of the complex, from the northsouth and starts at a driveway from the village, then goes to the east elevation of the palace, leading to the north bastion and the castle. This axis as a historical element, nowadays is a paved road marked by a lime alley (the trees represent the age group of 160-130). Until the 19th century it constituted the east border of a utility garden divided into sections.

The layout of the „old" park is not known, one can suppose on the basis of the remaining part of it that the complex had a geometrical character. The whole complex also comprised of the ponds which is mentioned in historical sources. Uneven terrain in front of the dikes can prove the existence of a terrace garden. The borders of the „new” and the „old" park remained unchanged since the inter-war period, apart from the south-east part including a group of the old oaks, which in 1946 was given to the farmers from the area.

\section{Summary}

The wealth and diversity of a cultural heritage of the present Podkarpackie voivodeship confirms the multicultural and multi-faith traditions of this region. Among the monuments entered in the register, the biggest number constitutes sacral architecture - 1022 objects. Residential architecture (castles, palaces and manors) represent 221 monuments and defensive -87 objects (The Provincial program for the protection of the historical Monuments in the Podkarpackie voivodeship in the years 2014-2017) [20]. All objects constitute elements of a landscape and show its quality and identity. Undertaken protection activities, in many cases of disappearing cultural landscapes should be an integral part of local, regional and national activities. They require a precise action, eg. context of an object in space. A good example of such revalorisation activities is a historical object in Rzemien - a residential-fortified tower from the first half of the 15 th century and soil bastion fortifications from the first half of the 17th century, in 2014 the winner of ,Zabytek Zadbany” (,Well - preserved Monument”) competition [21].

\section{References}

1. Ustawa o ochronie zabytków i opiece nad zabytkami z 23.07.2003 r. (Dz. U. pozycja 1568)

2. Decision on entering the register of monuments, (29.07.1971)

3. Studium uwarunkowań i kierunków zagospodarowania przestrzennego gminy Przeclaw, powiat mielecki, województwo podkarpackie, ustalenia, podstawy polityki przestrzennej gminy i kierunki zagospodarowania przestrzennego, 29 września (2000)

4. S. Mateszew, (Zarys dziejów osadnictwa w: Mielec. Studia i materiały z dziejów miasta i regionu. t. 2, (red.) F. Kiryk, (1988)

5. J. Teodorowicz - Czerepińska, (Zespót zabytków w Rzemieniu, pow. Mielec, woj. rzeszowskie. Wieża mieszkalno-obronna, fortyfikacje, park i pałac Szaszkiewiczów. 1959) za: T. Wierzbowski Matricularum Regni Poloniae - Summaria t. IV cz. I-III, (1910)

6. P. Miodunka, (Rezydencje obronne w okolicach Mielca (XIV-XVII w.) w: Rocznik Mielecki t. V (Samorządowe Centrum Kultury w Mielcu, 2002) 
7. J. Teodorowicz-Czerepińska, (Zespól zabytków w Rzemieniu, pow. Mielec, woj. rzeszowskie. Wieża mieszkalno-obronna, fortyfikacje, park i pałac Szaszkiewiczów. 1959) w posiadaniu Wojewódzkiego Biura Zabytków w Rzeszowie (maszynopis)

8. J. Piecuch, (Parki i osobliwości przyrody. w: Mielec. Studia i materiały z dziejówmiasta i regionu. t. 3, (red.) F. Kiryk, 1994)

9. M. Maciąga, (Zespót warowny w Rzemieniu, w: Mielec. Studia i materiały z dziejów miasta i regionu. t. 3, (red.) Kiryk F., Mielec, 994)

10. https://encyklopedia.pwn.pl/haslo/supraporta;3981459.html

11. F. Zacny (Inwentarz klucza rzemieńskiego z 1719 r. w: Rocznik Mielecki t. IV (Samorządowe Centrum Kultury w Mielcu, 2001)

12. A. Mamulski z zespołem, (Ewidencja zabytkowego parku, 1978/1979)

13. F. Sulimierski, B. Chlebowski, W. Walewski, (Stownik geograficzny Królestwa Polskiego i innych krajów słowiańskich. t. 10, 1889).

14. http://maps.mapywig.org/m/K.u.K._maps/series/075K/400dpi/ZONE_5_COL_XXV_ ROPCZYCE_und_DEBICA_1900_400dpi.jpg

15. M. Maciąga, (Zabytki sztuki regionu mieleckiego, w: Mielec. Studia i materiaty $z$ dziejów miasta i regionu. t. 1, (red.) F. Kiryk, 1984)

16. J. Skrzypczak, Działalność krakowskiego środowiska architektonicznego $w$ rejonie mieleckim $w$ dobie autonomii galicyjskiej 1867-1918. w: Dzieje lokalne pośród wydarzeń i procesów historycznych. Materiaty z sesji naukowej zorganizowanej pod patronatem honorowym Uniwersytetu Jagiellońskiego, wydane z okazji 550. rocznicy zezwolenia królewskiego na założenie miasta Mielca. (red.) K. Haptaś, (2007).

17. J. Sobiszewska, Zabytkowe podworskie ogrody i parki $w$ powiecie mieleckim, w: Rocznik mielecki, t.12-13. (red.) Haptaś K. Mielec. 2010

18. http://www.przeclaw.org/

19. Karta Ewidencyjna Zabytków Architektury i Budownictwa, obiekt: Wieża mieszkalno obronna Rzemień (Ośrodek dokumentacji zabytków w Warszawie, 2003)

20. Wojewódzki program opieki nad zabytkami w woj. podkarpackim na lata 2014-2017. Załącznik do uchwały NR XLII/846/14 Sejmiku Województwa Podkarpackiego z dnia 27 stycznia $2014 \mathrm{r}$.

21. A. Siwek, Rewaloryzacja przestrzeni kulturowej i krajobrazu, czyli zabytkowy krajobraz zadbany, w: Zabytek zadbany. Co to znaczy? (red.) Liżewska I.: 165-177 (NID, 2015) 